\title{
DETERMINATION OF NUTRITIVE VALUE AND ANTI-METHANOGENIC POTENTIAL OF TURKISH GRAPE POMACE USING IN VITRO GAS PRODUCTION TECHNIQUE
}

\author{
A. İ. Atalay \\ Igdır University, Faculty of Agriculture, Department of Animal Science, Igdır, Turkey \\ aliihsanatalay66@hotmail.com
}

\begin{abstract}
Grape pomace from the wine industry has been used in ruminant nutrition to meet the requirements of animals during shortages of conventional feed in most parts of the world. The aim of the current study was to screen Turkish grape pomaces (GPs) collected from various sites for chemical composition and anti-methanogenic potential using an in vitro gas production technique. Source had a significant effect on the chemical composition, gas production, methane $\left(\mathrm{CH}_{4}\right)$ production, metabolizable energy (ME), and organic matter digestibility (OMD) of some Turkish GPs. Crude ash (CA), ether extract (EE), crude protein (CP), neutral detergent fiber (NDF), acid detergent fiber (ADF), condensed tannin (CT) contents, gas production, $\mathrm{CH}_{4}$ production, $\mathrm{ME}$, and $\mathrm{OMD}$ values of the GPs were in the ranges of 3.90-9.37\%, 3.07$7.87 \%, 2.65-13.50 \%, 26.60-58.80 \%, 24.98-53.88 \%, 1.99-16.43 \%, 42.75-113.50 \mathrm{~mL}, 5.57-13.38 \mathrm{~mL}, 5.36-8.69 \mathrm{MJ} / \mathrm{kg}$ DM, and 39.87-61.27\%, respectively. The in vitro experiment showed that most of the GP samples studied have low $\mathrm{CH}_{4}$ mitigation potential. However, there is a need for in vivo experiments to test the mitigating potential of GP samples.
\end{abstract}

Key words: Grape pomace, chemical composition, digestibility, methane production.

https://doi.org/10.36899/JAPS.2020.4.0110

Published online April 25, 2020

\section{INTRODUCTION}

After the processing of grape fruits in the wine industry, a considerable amount of a byproduct called grape pomace (GP) becomes available in most parts of the world. GP has been used in ruminant nutrition to meet the requirements of animals during shortages of conventional feed, otherwise being a wasted product. It consists of seeds, pulp, skin, and stalk. The chemical composition of GP is variable and depends on the method of wine production, type of grape (Ruberto et al., 2008; Basalan et al., 2011), and relative ratios of components of the pomace (Baumgartel et al., 2007). It was also reported that there was a significant variation in condensed tannin (CT) contents of GP (Hixon et al., 2016). All these variations in chemical composition are likely to play a role in the nutritive value and antimethanogenic potential of GP. In addition to its nutritive value, GP also contains considerable amounts of $\mathrm{CT}$ with potential anti-methanogenic activity for ruminants (Hixson et al., 2016). It is well known that significant dietary energy loss occurs through enteric fermentation, which is one of the main contributors to greenhouse gasses (Johnson and Johnson, 1995). Recently, the inclusion of tannin-containing feeds in ruminant diets has been employed as a promising $\mathrm{CH}_{4}$ mitigation strategy (Bhatta et al., 2013; Bodas et al., 2012).

In vivo and in vitro experiments have recently indicated that feeding dairy cows in late lactation with GP with high tannin contents decreased methane $\left(\mathrm{CH}_{4}\right)$ production by approximately $20 \%$ without a concomitant reduction in dry matter (DM) intake (Pellikaan et al., 2011; Moate et al., 2014). Although considerable research has been carried out to determine the nutritive value of GP, including its chemical composition, metabolizable energy (ME), and organic matter digestibility (OMD), less attention has been paid to the anti-methanogenic potential of GP obtained from different sources.

The aim of the present study was to screen GP collected from various sources for anti-methanogenic potential using an in vitro gas production technique to determine the relationship between chemical composition and $\mathrm{CH}_{4}$ production.

\section{MATERIALS AND METHODS}

Grape pomace collection: The GP samples for the current experiment were obtained from 8 different companies in Turkey and dried in the shade (Table 1).

Chemical analysis of grape pomace: The GP samples were analyzed separately in the laboratory of the Animal Science Department, Faculty of Agriculture, Kahramanmaraş Sütçü İmam University, Turkey, in 2018. The GP samples were analyzed for DM, crude ash (CA), and ether extract (EE) contents (AOAC, 1990). Neutral detergent fiber (NDF) and acid detergent fiber (ADF) contents of the GP samples were analyzed with the method suggested by Van Soest et al. (1991). The CT contents of GP samples were analyzed with the butanol$\mathrm{HCl}$ method (Makkar et al., 1995). The water-soluble DM (WSDM) content of GP was estimated using nylon 
bags containing $2 \mathrm{~g}$ of GP samples washed with a

washing machine for 25 min (Ly and Preston, 1997).

Table 1. Grape pomace samples obtained from different companies.

\begin{tabular}{cl}
\hline Grape Pomace Samples & \multicolumn{1}{c}{ Company Name } \\
\hline GP1 & Aker Şarapçılık Tekirdağ, Turkey \\
GP2 & Bor-Sa Bortaçina Şarap Gıda San. Tic. Ltd. Şti, Balıkesir, Turkey \\
GP3 & Urla Şarapçllı Gida Turizm Tarım San A.Ş. İzmir, Turkey \\
GP4 & Kalecik Şarap Sanayi Tic. A.Ş, Ankara, Turkey \\
GP5 & Vinero Bağcllı San. Tic. A.Ş., Çanakkale, Turkey \\
GP6 & Tariş Sirke Pekmez İşletmesi, Manisa, Turkey \\
GP7 & Mey Alkollü İçkiler San Tic. A.Ş. Nevşehir, Turkey \\
GP8 & Erol Sahin, Karaman, Turkey \\
\hline
\end{tabular}

Determination of gas and methane production: The gas and $\mathrm{CH}_{4}$ production of GP samples was evaluated using the in vitro gas production (Menke et al., 1979). Rumen fluid was obtained from three Awassi sheep (approximately $50 \mathrm{~kg}$ average weight) fed with alfalfa hay (800 g) and barley grain (400 g). Before the morning feeding, an equal amount of rumen fluid from each sheep was taken into a thermo flask and filtered through four layered cheesecloths under flushing with $\mathrm{CO}_{2}$. The buffered rumen fluid $(40 \mathrm{~mL}, 1: 2 \mathrm{~V} / \mathrm{V})$ was taken into syringes containing approximately $500 \mathrm{mg}$ of GP samples and standard hay with known gas production in a bath set at $39{ }^{\circ} \mathrm{C}$. The same amount of buffered rumen fluid was transferred into syringes without substrate for blanks. All incubations were carried out in quadruplicate. The gas and $\mathrm{CH}_{4}$ production of the GP samples was measured after $24 \mathrm{~h}$ of incubation.

The ME (MJ/kg DM) and OMD of GP samples were estimated with the equations below (Menke and Steingass, 1988):

$\mathrm{ME}(\mathrm{MJ} / \mathrm{kg} \mathrm{DM})=2.20+0.1357 \mathrm{GP}_{24}+0.057 \mathrm{CP}+$ $0.00285 \mathrm{EE}^{2}$

$\mathrm{OMD}(\%)=14.88+0.8893 \mathrm{GP}_{24}+0.448 \mathrm{CP}+0.651 \mathrm{CA}$

$\mathrm{GP}_{24}$ : Gas production $(\mathrm{mL})$ at $24 \mathrm{~h}$ of incubation

CP: Crude protein (\% of DM)

EE: Ether extract ( $\%$ of DM)

CA: Crude ash (\% of DM)

The $\mathrm{CH}_{4}$ of total gas production after $24 \mathrm{~h}$ of incubation of GP samples was analyzed with an infrared methane analyzer (Sensor Europe GmbH, Erkrath, Germany) (Goel et al., 2008) and presented as $\mathrm{mL}$ and percentage.

$\mathrm{CH}_{4}$ production $(\mathrm{mL})=$ Total gas production $(\mathrm{mL}) \times$ Percentage of $\mathrm{CH}_{4}(\%)$

Statistical analyses: One-way analysis of variance (ANOVA) was used to differentiate among the sources of the GP samples. Differences $(\mathrm{P}<0.05)$ among the means of GP samples were determined with Tukey's multiple range tests. Pearson correlation coefficients were calculated to show the relationship between chemical composition and in vitro gas production parameters. All statistical analyses were carried out using SPSS (2011).

\section{RESULTS AND DISCUSSION}

The chemical compositions of some Turkish GP samples are presented in Table 2. Source significantly affected the chemical composition of the GP samples. Crude ash contents varied between $3.90 \%$ and $9.37 \%$, with the highest values in GP2 and GP6 and the lowest in GP8. Ether extract contents ranged from $3.07 \%$ to $7.87 \%$, with the highest values in GP1 and the lowest in GP6. It was found that crude protein contents varied considerably within the GP samples, ranging from $2.65 \%$ to $13.50 \%$; the highest values were found in GP7 and the lowest in GP5. There was also significant variation in the NDF contents of the GP samples, ranging from $26.60 \%$ to $58.80 \%$, with the highest values in GP1 and GP4 and the lowest in GP8. The ADF contents of the GP samples varied from $24.98 \%$ to $53.88 \%$, the highest values being seen in GP1 and the lowest in GP8. The CT contents of the GP samples varied between $1.99 \%$ and $16.43 \%$, the highest values being seen in GP1 and GP4 and the lowest in GP6 and GP8. These results are consistent with the findings of Hixson et al. (2016), who reported that the $\mathrm{CA}, \mathrm{EE} \mathrm{CP}, \mathrm{NDF}, \mathrm{ADF}$, and CT of GP samples were in the ranges of $3.12-8.49 \%, 1.3-17.4 \%, 3.2-14.4 \%, 18.4-$ $61.4 \%, 16.2-56.1 \%$, and $0.69-13.8 \%$, respectively. As can be seen from Table 2, there is significant variation among the Turkish GP samples in terms of chemical composition. These variations among GP samples are possibly related to wine production method, type of grape, and relative ratios of components of the grape pomace (Zalikarenab et al., 2007; Baumgartel et al., 2007; Ruberto et al., 2008; Basalan et al., 2011; Winkler et al., 2015).

CT in feedstuffs may have adverse or beneficial effects on animals depending on the amount and chemical structure (Makkar, 2003; Min et al., 2003; MuellerHarvey, 2006). Although low levels of CT (2-3\% of DM) may have beneficial effects, preventing protein from 
extensive degradation, high CT levels $(6 \%$ and $10 \%$ of $\mathrm{DM})$ were found to reduce the intake and growth of animals (Barry et al., 1984). The studied GP samples, except for GP6 and GP8, may have detrimental effects on rumen fermentation and animal performance because of their high CT contents. However, high levels of CT may provide a good opportunity to reduce the supplementation amount of GP in the ruminant diet to make use of the anti-methanogenic potential of the CT.

The gas production, $\mathrm{CH}_{4}$ production, $\mathrm{ME}$, and OMD of the Turkish GP samples are presented in Table 3. These values ranged from 42.75 to $113.50 \mathrm{~mL}, 5.57$ to $13.38 \mathrm{~mL}, 5.36$ to $8.69 \mathrm{MJ} / \mathrm{kg} \mathrm{DM}$, and $39.87 \%$ to $61.27 \%$, respectively.

Table 2. The chemical composition of some Turkish grape pomaces obtained from different companies.

\begin{tabular}{|c|c|c|c|c|c|c|c|}
\hline Type & DM & $\mathbf{C A}$ & EE & $\mathbf{C P}$ & NDF & ADF & CT \\
\hline GP1 & $92.95^{\mathrm{a}}$ & $6.89^{\mathrm{b}}$ & $7.87^{b}$ & $11.78^{\mathrm{bc}}$ & $57.99^{\mathrm{a}}$ & $53.88^{\mathrm{a}}$ & $16.43^{\mathrm{a}}$ \\
\hline GP2 & $92.39^{\mathrm{ab}}$ & $9.32^{\mathrm{a}}$ & $4.29^{\mathrm{d}}$ & $12.62^{\mathrm{ab}}$ & $49.84^{b}$ & $44.47^{c}$ & $14.39^{\mathrm{a}}$ \\
\hline GP3 & $92.76^{\mathrm{ab}}$ & $7.17^{b}$ & $6.33^{c}$ & $12.18^{\mathrm{bc}}$ & $48.21^{\mathrm{c}}$ & $43.70^{c}$ & $10.13^{b}$ \\
\hline GP4 & $92.93^{\mathrm{a}}$ & $5.87^{\mathrm{c}}$ & $9.23^{\mathrm{a}}$ & $11.33^{\mathrm{cd}}$ & $58.80^{\mathrm{a}}$ & $50.06^{b}$ & $16.06^{\mathrm{a}}$ \\
\hline GP5 & $91.05^{\mathrm{bc}}$ & $4.28^{\mathrm{d}}$ & $6.98^{\mathrm{c}}$ & $2.65^{f}$ & $37.22^{\mathrm{e}}$ & $37.00^{\mathrm{de}}$ & $14.08^{\mathrm{a}}$ \\
\hline GP6 & $91.57^{\mathrm{ab}}$ & $9.37^{\mathrm{a}}$ & $3.07^{\mathrm{e}}$ & $10.36^{\mathrm{d}}$ & $45.60^{\mathrm{d}}$ & $39.01 \mathrm{~d}$ & $1.99^{c}$ \\
\hline GP7 & $92.22^{\mathrm{ab}}$ & $6.70^{\mathrm{bc}}$ & $3.98^{\mathrm{d}}$ & $13.50^{\mathrm{a}}$ & $49.58^{b c}$ & $35.42^{\mathrm{e}}$ & $14.37^{\mathrm{a}}$ \\
\hline GP8 & $89.39^{c}$ & $3.90^{\mathrm{d}}$ & $3.94^{\mathrm{d}}$ & $5.03^{\mathrm{e}}$ & $26.60^{f}$ & $24.98^{f}$ & $3.55^{\mathrm{c}}$ \\
\hline SEM & 0.512 & 0.264 & 0.185 & 0.313 & 0.313 & 0.641 & 1.117 \\
\hline Sig. & *** & $* * *$ & $* * *$ & $* * *$ & $* * *$ & $* * *$ & $* * *$ \\
\hline
\end{tabular}

${ }_{a b c}$ Column means with common superscripts do not differ $(P>0.05)$. SEM: Standard error of the mean.

Table 3. The gas production, methane production, metabolizable energy, and organic matter digestibility of some Turkish grape pomaces obtained from different companies.

\begin{tabular}{|c|c|c|c|c|c|c|}
\hline Type & Gas & $\mathrm{CH}_{4}(\mathrm{~mL})$ & $\mathrm{CH}_{4}(\%)$ & ME (MJ/kg DM) & OMD (\%) & WSDM (\%) \\
\hline GP1 & $42.75^{\mathrm{f}}$ & $5.57^{\mathrm{d}}$ & 13.04 & $5.36^{\mathrm{f}}$ & $39.85^{\mathrm{d}}$ & $34.50^{\mathrm{d}}$ \\
\hline GP2 & $77.50^{d}$ & $10.82^{b c}$ & 13.96 & $7.17^{\mathrm{c}}$ & $54.16^{\mathrm{b}}$ & $35.99^{d}$ \\
\hline GP3 & $67.50^{\mathrm{e}}$ & $9.99^{c}$ & 14.84 & $6.67^{d}$ & $49.01^{\mathrm{c}}$ & $43.14^{\mathrm{cd}}$ \\
\hline GP4 & $50.50^{\mathrm{f}}$ & $6.45^{\mathrm{d}}$ & 12.78 & $5.83^{e}$ & $41.74^{\mathrm{d}}$ & $39.33^{\mathrm{cd}}$ \\
\hline GP5 & $85.75^{\mathrm{c}}$ & $10.57^{\mathrm{c}}$ & 12.32 & $7.14^{\mathrm{c}}$ & $49.35^{\mathrm{c}}$ & $54.70^{\mathrm{b}}$ \\
\hline GP6 & $100.25^{\mathrm{b}}$ & $13.38^{\mathrm{b}}$ & 13.31 & $8.25^{\mathrm{ab}}$ & $61.27^{\mathrm{a}}$ & $46.27^{\mathrm{bc}}$ \\
\hline GP7 & $94.75^{b}$ & $12.54^{\mathrm{bc}}$ & 13.24 & $8.15^{b}$ & $58.99^{\mathrm{a}}$ & $35.21^{\mathrm{d}}$ \\
\hline GP8 & $113.50^{\mathrm{a}}$ & $16.08^{\mathrm{a}}$ & 14.17 & $8.69^{a}$ & $60.04^{\mathrm{a}}$ & $67.39^{\mathrm{a}}$ \\
\hline SEM & 2.479 & 0.787 & 0.760 & 0.134 & 0.881 & 2.942 \\
\hline Sig. & $* * *$ & $* * *$ & NS & $* * *$ & $* * *$ & $* * *$ \\
\hline
\end{tabular}

a bc Column means with common superscripts do not differ (P>0.05). SEM: Standard error of the mean.

The gas productions and OMD of the GP samples in the current study were comparable to the values previously reported by Moghaddam et al. (2013) and Mirzaei-Aghsaghali et al. (2011), who found that gas production of GP samples ranged from 56.05 to 63.43 $\mathrm{mL}$ and $77.3 \mathrm{~mL} / 500 \mathrm{mg}$, respectively. However, the gas and $\mathrm{CH}_{4}$ production of the GP samples in the current study were lower than those reported by Hixon et al. (2018), although the percentage values of $\mathrm{CH}_{4}$ and $\mathrm{ME}$ for these GP samples were comparable and fell into the range between 6.6 and $12 \mathrm{MJ} / \mathrm{kg} \mathrm{DM}$ as reported by Hixon et al. (2018). The differences between these two experiments in terms of gas and $\mathrm{CH}_{4}$ production seem to be related to differences in the chemical composition of the utilized GP samples.

Correlation coefficients (r) of the relationship of chemical composition with in vitro gas production and the estimated parameters are given in Table 4. The EE, NDF, ADF, and CT of the GP samples are negatively related to the gas production $(\mathrm{mL}), \mathrm{CH}_{4}$ production $(\mathrm{mL})$, $\mathrm{ME}$, and OMD of GP samples. On the other hand, the WSDM content was significantly correlated with the gas production, $\mathrm{CH}_{4}(\mathrm{~mL})$, and $\mathrm{ME}$ of the GP samples. It was reported that cell wall contents and CT contents were negatively related to gas production, OMD, and $\mathrm{ME}$ of tannin-containing feedstuffs (Camacho et al., 2010; Kaplan, 2011; Rezaeenia et al., 2016). Gas production, including $\mathrm{CH}_{4}$, depends not only on the amount of the available fermentable substrate but also on the amount and molar proportions of the volatile fatty acids produced during fermentation (Davies et al., 2000). Although the contribution of the protein and fat in the diet to gas production is small or negligible when compared with carbohydrate fermentation, high levels of fat in ruminant 
diets may have a negative effect on the gas and $\mathrm{CH}_{4}$ production. The negative relationship between gas production or $\mathrm{CH}_{4}$ and $\mathrm{EE}$ content of the GPs obtained in the current experiment supports this hypothesis. Fat exerts its negative effects on gas and $\mathrm{CH}_{4}$ production through inhibition of the activity of methanogens and protozoans and the biohydrogenation of fatty acid in oil (Johnson and Johnson, 1995).

Table 4. Relationship of chemical composition with in vitro gas production and estimated parameters of some Turkish grape pomaces.

\begin{tabular}{|c|c|c|c|c|c|c|c|}
\hline \multirow[b]{2}{*}{ Parameters } & \multicolumn{7}{|c|}{ Chemical composition } \\
\hline & CA & $\mathrm{EE}$ & $\mathrm{CP}$ & NDF & ADF & CT & WSDM \\
\hline Gas $(\mathrm{mL})$ & $-0.140^{\mathrm{NS}}$ & $-0.844^{* * *}$ & $-0.429^{*}$ & $-0.830^{* *}$ & $-0.944^{* *}$ & $-0.718^{* *}$ & $0.632^{* *}$ \\
\hline $\mathrm{CH}_{4}(\mathrm{~mL})$ & $-0.103^{\mathrm{NS}}$ & $-0.830^{* *}$ & $-0.360^{\mathrm{NS}}$ & $-0.830^{* *}$ & $-0.938^{* *}$ & $-0.759^{* *}$ & $0.632^{* *}$ \\
\hline $\mathrm{CH}_{4}(\%)$ & $0.240^{\mathrm{NS}}$ & $-0.403^{\mathrm{NS}}$ & $0.298^{\mathrm{NS}}$ & $-0.218^{\mathrm{NS}}$ & $-0.219^{\mathrm{NS}}$ & $0.406^{\mathrm{NS}}$ & $0.117^{\mathrm{NS}}$ \\
\hline $\mathrm{ME}(\mathrm{MJ})$ & $-0.046^{\mathrm{NS}}$ & $-0.888^{* *}$ & $-0.296^{\mathrm{NS}}$ & $-0.752^{* *}$ & $-0.914^{* *}$ & $-0.711^{* *}$ & $0.539^{* *}$ \\
\hline OMD (\%) & $0.162^{\mathrm{NS}}$ & $-0.956^{* *}$ & $-0.128^{\mathrm{NS}}$ & $-0.631^{* *}$ & $-0.816^{* *}$ & $-0.708^{*}$ & $0.393^{\mathrm{NS}}$ \\
\hline
\end{tabular}

Another factor affecting gas and $\mathrm{CH}_{4}$ production is the CT contents of the GP samples. As can be seen from Table 4, CT was negatively correlated with gas and $\mathrm{CH}_{4}$ production since $\mathrm{CT}$ has the ability to complex with carbohydrate and protein in the substrate, reducing the availability of fermentable substrate for rumen microorganisms (Patra, 2010; Jayanegara et al., 2011). CT contents also have a significant detrimental effect on the activity of microorganisms including bacteria, protozoans, and archaeans, depending on the amount and polymerization of CT (Goel et al., 2005; Tavendale et al., 2005; McSweeney et al., 2011; Galindo et al., 2008; Min et al., 2014).

A number of reviews indicated that $\mathrm{CT}$ and fat had significant enteric $\mathrm{CH}_{4}$ mitigation potential (Henry and Eckard, 2009; Eckard et al., 2010). An in vivo experiment with dairy cows in late lactation showed that supplementation of the diet with GP decreased the enteric $\mathrm{CH}_{4}$ emission by approximately $20 \%$ without compromising DM intake. The reduction in $\mathrm{CH}_{4}$ emission due to GP supplementation is possibly associated with the EE, CT, lignin, and tartaric acid contents of GP (Moate et al., 2014). The current experiment clearly showed that several of the GPs tested here contained various amounts of $\mathrm{CT}$ and EE, which negatively correlated with $\mathrm{CH}_{4}$ production.

The $\mathrm{CH}_{4}$ mitigation potential of feedstuffs has recently been determined using the percentage of $\mathrm{CH}_{4}$ of gas produced after $24 \mathrm{~h}$ of incubation (Lopez et al., 2010). The GP samples of the present study, except for GP3, have low $\mathrm{CH}_{4}$ reduction potential since the percentage of $\mathrm{CH}_{4}$ in the gas fell into the range of 11$14 \%$, which was categorized as low potential by Lopez et al. (2010).

In conclusion, there is a considerable amount of variation among the GP samples studied in the current work in terms of chemical composition, in vitro gas production, $\mathrm{CH}_{4}$ production, $\mathrm{ME}$, and $\mathrm{OMD}$. Most of the GP samples studied here have low $\mathrm{CH}_{4}$ mitigation potential. Therefore, GP may be included in ruminant diets to mitigate $\mathrm{CH}_{4}$ emissions. However, there is a need for in vivo experiments to test the mitigating effects of GP samples.

\section{REFERENCES}

AOAC (1990) Official method of analysis. $15^{\text {th }}$ ed., pp.66-88. Association of official analytical chemists, Washington, DC, USA. 1990.

Barry T.N., T.R. Manley, and J.S. Duncan (1984). The role of condensed tannins in the nutritional value of Lotus pedunculatus for sheep intake. Brit. J. Nutr. 51: 485-491.

Barry, T.N. (1987). Secondary compounds of forages. In, Hacker JB, Ternouth JH (Eds): Nutrition of Herbivores. 91-120, Academic Press, Sydney,

Basalan, M., T. Gungor, F.N. Owens, and I. Yalcinkaya (2011). Nutrient content and in vitro digestibility of Turkish grape pomaces. Anim. Feed Sci. Technol. 169: 194-198.

Baumgartel, T., H. Kluth, K. Epperlein, and M. Rodehutscord (2007). A note of digestibility and energy value for sheep of different grape pomace. Small Rum. Res. 67:302-306.

Bhatta, R., M. Saravanan, L. Baruah, K. T. Sampath, and C.S. Prasad (2013). Effect of plant secondary compounds on in vitro methane, ammonia production and ruminal protozoa population. J. Appl. Microbiol. 115: 455-65.

Bodas, R., N. Prieto, R. Garcia-Gonzalez, S. Andres, F.J. Giraldez, and S. Lopez (2012) Manipulation of rumen fermentation and methane production with plant secondary metabolites. Anim. Feed Sci. Technol. 176: 78-93.

Camacho, L.M., R. Rojo A.Z.M. Salem, G.D. Mendoza, D. Lopez, J.L. Tinoco, B. Albarran, and O.D. Montanez-Valdez (2010). In vitro ruminal fermentation kinetics and energy utilization of three Mexican tree fodder species during the 
rainy and dry period. Anim.Feed Sci. Tecnol. 160(3-4):110-120.

Davies, Z. S., D. Mason, A. E. Brooks, G. W. Griffith, R. J. Merry, and M. K. Theodorou. (2000). An automated system for measuring gas production from forages inoculated with rumen fluid and its use in determining the effect of enzymes on grass silage. Anim. Feed Sci. Technol. 83:205221.

Eckard, R. J., C. Grainger, and C.A.M de Klein (2010) Options for the abatement of methane and nitrous oxide from ruminant production: A review. Livest. Sci. 130: 47-56.

Galindo J, N. González, D. Delgado, A. Sosa, Y. Marrero, R. González, AI. Aldama, and O Moreira (2008). Efecto modulador de Leucaena leucocephala sobre la microbiota ruminal. Zootecn. Trop. 26: 249-252.

Goel, G., A.K. Puniya, C.N. Aguilar, and K. Singh. (2005). Interaction of gut microflora with tannins in feeds. Naturwissenschaften 92, 497503.

Goel, G., H.P.S. Makkar, and K. Becker (2008). Effect of Sesbania sesban and Carduus pycnocephalus leaves and Fenugreek (Trigonella foenumgraecum L) seeds and their extract on partitioning of nutrients from roughage and concentrate-based feeds to methane. Anim. Feed Sci. Technol. 147 (1-3): 72-89.

Henry, B and R. Eckard (2009) Greenhouse gas emissions in livestock production systems. Trop. Grassl. 43: 232-238.

Hixon, J.L., J. L.Jacobs, E.N. Wilkes, and P.A. Smith (2016). Survey of the variation in grape marc condensed tannin composition and concentration and analysis of key compositional factors. J. Agric. Food Chem. 64:7076-7086.

Jayanegara, A, E. Wina, C.R. Soliva, S. Marquardt, M. Kreuzer, and F. Leiber (2011). Dependence of forage quality and methanogenic potential of tropical plants on their phenolic fractions as determined by principal component analysis. Anim. Feed Sci. Technol. 163:231-243.

Johnson, K.A. and D.E. Johnson (1995) Methane emissions from cattle. J Anim. Sci. 73:24832492.

Kaplan, M. (2011). Determination of potential nutritive value of sainfoin (Onobrychis sativa) hays harvested at flowering stage. J. Anim Vet. Adv. 10(15):2028-2031.

Lopez, S., H.P.S. Makkar, and C.R. Soliva (2010). Screening plants and plant products for methane inhibitors. In, Vercoe PE, Makkar HPS, Schlink A (Eds): In vitro Screening of Plant Resources for Extra-nutritional Attributes in Ruminants:
Nuclear and Related Methodologies. pp.191231, London, New York.

Ly, J. and T.R. Preston (1997) An approach to the estimation of washing losses in leaves of tropical trees. Livestock Research for Rural Development. Volume 9, Article \#22. Retrieved January 29, 2018, from http://www.lrrd.org/lrrd9/3/ly931.htm

Makkar, H.P.S. (2003). Effects and fate of tannins in ruminant animals, adaptation to tannins, and strategies to overcome detrimental effects of feeding tannin-rich feeds. Small Rumin. Res. 49:241-256.

Makkar, H.P.S., M. Blümmel, and K. Becker (1995) Formation of complexes between polyvinyl pyrrolidones or polyethylene glycols and their implication in gas production and true digestibility in vitro techniques. Brit. J. Nutr. 73: 897-913.

McSweeney, C.S., B. Palmer, R. Bunch, and D.O. Krause (2001). Microbial interactions with tannins: nutritional consequences for ruminants. Anim. Feed. Sci. Technol. 91: 83-93.

Menke, K.H, L. Raab, A Salewski, A, H. Steingass, D. Fritz, and W. Schneider (1979) The estimation of the digestibility and metabolizable energy content of ruminant feedingstuffs from the gas production when they are incubated with rumen liquor in vitro. J Agric. Sci. (Camb) 93:217-222.

Menke, K.H. and H. Steingass (1988). Estimation of the energetic feed value obtained from chemical analysis and in vitro gas production using rumen fluid. Anim. Res. Dev.1988:28:7-55.

Min, B. R., T.N. Barry, G.T. Attwood, and W.C. McNabb (2003). The effect of condensed tannins on the nutrition and health of ruminants fed fresh temperate forages: a review. Anim. Feed Sci. Technol. 106 (1-4): 3-19

Min, B.R., S. Solaiman, R. Shange, and J.S. Eun (2014). Gastrointestinal bacterial and methanogenic archaea diversity dynamics associated with condensed tannin-containing pine bark diet in goats using $16 \mathrm{~S}$ rDNA amplicon pyrosequencing. Int. J. Microbial. 11 pages. http://dx.doi.org/10.1155/2014/141909

Mirzaei-Aghsaghali, A., N. Maheri-Sis, H. Mansouri, M.E. Razeghi, A.S. Telli, and A. AghajanzadehGolshani (2011). Estimation of the nutritive value of grape pomace for ruminant using gas production technique. Afr. J. Biotechnol. 10(33):6246-6250.

Moate, P.J., S.R.O., Williams, V.A., Torok, M.C. Hannah, B.E., Ribaux, M.H. Tavendale, R.J, Eckard, J.L, Jacops, M. J. Auldis, and W.J. Wales (2014). Grape marc reduces methane 
emissions when fed to dairy cows. J. Dairy Sci. 97(8): 5073-5087.

Moghaddam, M., A. Taghizadeh, A. Nobakht, and A. Ahmadi (2013). Determination of metabolisable energy of grape pomace and risin Vitis leaves using in vitro gas production technique. Anim. Prod. 15(1):40-46.

Mueller-Harvey, I. 2006. Unravelling the conundrum of tannins in animal nutrition and health. J. Sci. Food Agric. 86:2010-2037.

SPSS (2011) IBM Corp. Released 2011. IBM SPSS Statistics for Windows, Version 20.0. Armonk, NY: IBM Corp

Patra, A.K. (2010). Meta-analyses of effects of phytochemicals on digestibility and rumen fermentation characteristics associated with methanogenesis. J. Sci. Food Agr. 90: 27002708.

Pellikaan W.F., E. Strigano, J. Leenaars, D.J.G.M. Bongers, S. van Laar-van Schuppen, J. Plant, and I. Mueller-Harvey (2011). Evaluating effects of tannins on extent and rate of in vitro gas and $\mathrm{CH}_{4}$ production using an automated pressure evaluation system (APES). Anim. Feed Sci. Technol. 166-167:377-390.

Rezaeenia A, A.A. Naserian, and A. Mokhtarpour (2016). Chemical composition, fatty acids profile and biological evaluation of tannins of selected date seeds grown in Iran. Iranian J. Appl. Anim. Sci. 6(3):517-524.

Ruberto, G., A. Renda, V. Amico, and C. Tringali (2008). Volatile components of grape pomaces from different cultivars of Sicilian Vitis vinifera L. Bioresour. Technol. 99:260-268

Tavendale, M.H, L.P. Meagher, D. Pacheco, N Walker, G.T Attwood, and S Sivakumaran. (2005). Methane production from in vitro rumen incubations with Lotus pedunculatus and Medicago sativa, and effects of extractable condensed tannin fractions on methanogenesis. Anim. Feed Sci. Technol. 123-124: 403-419.

Van Soest, P.V., J.B. Robertson, and B.A. Lewis (1991). Methods for dietary fiber, neutral detergent fiber, and nonstarch polysaccharides in relation to animal nutrition. J Dairy Sci. 74(10): 35833597

Winkler A, F. Weber, R. Ringseis, K. Eder, and G. Dusel (2015). Determination of polyphenol and crude nutrient content and red grape pomace cultivars. Arch. Anim. Nutr. 69(3):187-200.

Zalikarenab, L, R. Pirmohammadi, and A. Teimuriyansari (2007). Chemical composition and digestibility of dried white and red grape pomace for ruminants. J. Anim. Vet. Adv. 6(9):1107-1111. 